Original Research Paper

\title{
Asteraceae Diversity and A New Record For Java at Citalahab Village, Gunung Halimun-Salak National Park
}

\author{
Dee Dee Al Farishy ${ }^{1,2} \&$ Andi Salamah ${ }^{3}$ \\ ${ }^{1}$ Organisasi Mahasiswa Pecinta Tumbuhan (OMPT) Canopy, Departemen Biologi, FMIPA Universitas \\ Indonesia, Depok, Indonesia \\ ${ }^{2}$ Health Science Cluster, Universitas Indonesia, Depok, Indonesia \\ ${ }^{3}$ Departemen Biologi, FMIPA Universitas Indonesia, Depok, Indonesia
}

\author{
Article History \\ Received : April 21th, 2021 \\ Revised : May $05^{\text {th }}, 2021$ \\ Accepted : May $11^{\text {th }}, 2021$ \\ Published : May $18^{\text {th }}, 2021$ \\ *Corresponding Author: \\ Dee Dee Al Farishy \\ Organisasi Mahasiswa Pecinta \\ Tumbuhan (OMPT) Canopy, \\ Departemen Biologi, FMIPA \\ Universitas Indonesia, Depok, \\ Indonesia \\ Email: \\ deedee.alfarishy@alumni.ui.ac.id
}

\begin{abstract}
Asteraceae is the second largest plant family in the world. The family member has reached 227 species in Java. However, there is no current record of wild Asteraceae around local village within Gunung Halimun-Salak National Park. This study is to provide current Asteraceae species data and the threat for the conservation area. Explorative method has been conducted in 6 sites. The result shows that there are 20 species found with the tribes composition are 8 Heliantheae, 6 Eupatorieae, 3 Senecioneae, 1 Astereae, 1 Cichorieae, and 1 new record Vernonieae in Java. Key identification for species are provided and the new record has been described. Most species categorized as introduced with several other categorized as invasive alien species. In conclusion, numbers of Asteraceae family has been recorded with some potential ivansive threat in Gunung Halimun-Salak National Park. Regular population control and treatment are recommended in order to protect native species in the conservation area.
\end{abstract}

Keywords: Asteraceae, Elephantopus mollis, Halimun-Salak, tea plantation

\section{Introduction}

Asteraceae Bercht. \& J. Presl are the second largest genera in the world with about 1623 genera and 24.700 spesies (Funk, et al., 2009; Shi, et al., 2011; Christenhusz \& Byng, 2016). The family could be found abundantly with high number of diversity, start from tropical, subtropical, semi-arid, to mediteranian area. Besides, Asteraceae could also grow from sea level to alpin zone (Cox, et al., 2016). Majority of Asteraceae member are easily wide spreading far by wind in seeds and adaptable across area or even continent (Pons, et al. 1987; Keeley, et al. 2007; Jeffrey, 2009).

Based on Flora of Java and updated data after, it has been recorded that there are about 227 species Asteraceae occur in Java (Backer \& Bakhuizen van den Brink, 1965; Irsyam \& Hariri, 2016; Padmanaba, et al. 2017). Many of the species are known as introduced or even invasive alien species (Backer \& Bakhuizen van den Brink, 1965; Yoshihumi, et al. 2014). That absolutely could become latent danger for native species, especially in conservation area.

Gunung Halimun-Salak National Park is a unique location. The national park are surrounded by Mount Halimun Utara (1.929 m asl), Mount Ciawitali (1.530 m asl), Mount Kencana (1.831 m asl), Mount Botol $(1.850 \mathrm{~m}$ asl), Mount Sanggabuana (1.920 m asl), Mount Kendeng Selatan (1.680 m asl), Mount Halimun Selatan (1.758 m asl), Mount Endut (1.471 m asl), Mount Sumbul (1.926 m asl), and Mount Salak (2211 m asl) (Hartono et al. 2007). However, there are villages and tea plantation inside layers of mountain which not include in conservation site area (Wisnubudi, 2009). Uji (2002) has found seven species Asteraceae in southern part of the National Park, Priyadi, et al. (2010) has made checklist for five hundred 
species of Halimun-Salak, and Sunaryo, et al. (2012) has recorded there are two introduced species Asteraceae grow with one of that occur as invasive species. However, there are no whole new checklist data about Asteraceae, especially inside tea plantation. Aim of this research is to report current data about Asteraceae species at the tea plantation. The result hopefully helpful to protect conservation area around from introduced and invasive alien species taxa.

\section{Material and Methods}

\section{Sites}

Field observation were done at Nirmala tea plantation and surround area, Citalahab Village, Inside non-conservation site of Gunung Halimun-Salak National Park (1002-1149 m asl) on January 2019. There are 6 locations for field samplings.

1. Rice fields (RF: S $06^{0} 44.364^{\prime}$ E $106^{0}$ 31.842').

2. Upper village/Citalahab Bedeng (VI: S $06^{0} 44.110^{\prime}$ E $106^{0} 31.780^{\prime}$ )

3. Tea plantation 1 (TP1: S $06^{0} 44.346^{\prime} \mathrm{E}$ $\left.106^{0} 31.967^{\prime}\right)$.

4. Tea plantation 2 (TP2: S $06^{0} 44.238^{\prime} \mathrm{E}$ $\left.106^{0} 31.950^{\prime}\right)$

5. Tea plantation 3 (TP3: S $06^{0} 44.575^{\prime} \mathrm{E}$ $\left.106^{0} 32.403^{\prime}\right)$.

6. Near Curug Macan (Macan Waterfall) (CM: S $06^{\circ} 44.768^{\prime}$ E $\left.106^{\circ} 32.400^{\prime}\right)$.

\section{Material}

Material used are scissor, graduated ruler, pencils, notebook, black backdrop, alcohol $70 \%$, newspapers sheet, Global Positioning System (GPS) Garmin 64S and camera NIKON Coolpix P520.

\section{Plants Sampling}

Explorative method is used with $20 \times 20$ meters roaming area. Dried herbarium specimens had been made using $70 \%$ alcohol. Following characters had been identified and descripted by measuring size and shape of the stems, leaves, florets, and cypsela. Data analysis and key identification had been made descriptively. Herbarium stored at Department Biology, Faculty Mathematics and Natural Sciences, Universitas Indonesia.

\section{Result and Discussion}

\section{Asteraceae Diversity}

There were found 20 wild Asteraceae species during field observation in Nirmala tea plantation at Gunung Halimun-Salak National Park, West Java, in January 2019 (fig. 1). Most of species had been found common at RF, VI, TP1, TP2, and TP3, but absent at CM, Ayapana triplinervis had only found at RF, Lactuca indica had only found at VI, and Adenostemma lavenia had only found around CM (table 1). Adensotemma. lavenia had seen with uncommon habit for Asteraceae because the species could grow under the shade of trees. Moreover, the species had been seen spread extend to the forest within conservation site.

One of the species are related to Elephantopus genera. It was certainly not the one that reported from Flora of Java (Backer \& Bakhuizen van den Brink, 1965). The species similar to E. scaber by sessile heads with three foliage bract, but differ by white flowers color and florets position that emerge in axillar and terminal. Therefore, an examination for the species has been done.

\section{Key for species:}

1a Flower homogamous .......................................2

1b Flower heterogamous ....................................11

2a Flower obviously ligulate. Corolla yellow, with 5 lobes at apex. Leaves subcoriaceous. Sap often milky. Lactuca indica

$2 \mathrm{~b}$ Flower rather tubular .3

3a Style-arms longer than corolla, glomerulate or glomeruliform 4

3b Style-arms short 9

4a Plant twining Mikania micrantha $4 \mathrm{~b}$ Plant terrestrial erect 5

5a Heads rather scattered on terminal paniculiform. Cypsela tuberculate and sticky......................................... Adenostemma lavenia

$5 b$ Heads in paniculiform corymbs and dense. ...... 6

6a Herb to small shrub about $1 \mathrm{~m}$ or less.......... 7 6b Large shrub $2 \mathrm{~m}$ or more............................... 8 
7a Flower about 20, corolla about $6 \mathrm{~mm}$ long, white. Leaves oblong to lanceolate, with glabrous or subglabrous surface ........Ayapana triplinervis 7b Flower 60-75, corolla 1-1,5 mm long, white or purple. Leaves broadly ovate, triangularovate, or rhomboid-ovate, both surface covered with long hair Ageratum conyzoides

8a Heads $1-2 \mathrm{~cm}$ long, flower white to bright purple. Stem often has swollen globose part. Chromolaena odorata

8b Heads small, 5-6 mm long .Austroeupatorium inulaefolium

9a Head discoid. Receptacle paleate. Bear only up to 4 flowers. Flower white, zygomorph with 5 lobes. Elephantopus mollis (Fig. 2) $9 \mathrm{~b}$ Head cylindric, more or less elongate. Receptacle epaleate. Involucre mostly calyculate

10a Involucre calyculate. Heads nodding during anthesis, erect after.

\section{Crassocephalum crepidioides}

$10 \mathrm{~b}$ Involucre without calyculate on outer layer Emilia sonchifolia

11a Ray flower inconspicious or filiform. Heads cylindric or disciform. .. 12 11b Ray flower conspicious and ligulate. Heads radiate or discoid

12a Cypsela without hairy pappus, exocarp fleshy and endocarp stony, with black persistent involucre. Flowers white.

Clibadium surinamense

12b Cypsela with hairy pappus 13

13a Head disciform. Pappus yellow or brownish

Erigeron sumatrensis 13b Head cylindric. Pappus white with red or purple at the upper part. Involucre calyculate

\section{Erechtites valerianifolia}

14a Ray flower yellow 15 14b Ray flower white. 18

15a Pappus present, 2-3. Cypsela $1-3 \mathrm{~mm}$. Heads conical Acmella paniculata
$15 \mathrm{~b}$ Pappus reduced to awned or wanting. 16

16a Pappus awned Calyptocarpus vialis 16b Pappus wanting 17

17a Ray flower about $15 \mathrm{~mm}$ long. Basal leaves often with 3 lobes, margin serrate Sphagneticola trilobata 17b Ray flower 5-7 mm long. Leave simple, margin crenate-serrate ........Synederella nodiflora

18a Leaves imparipinnate Bidens pilosa $18 \mathrm{~b}$ Leaves simple. 19

19a Ray flower 4-5. Pappus present

19b Ray flower numerous. Pappus
wanting
Eclipta prostrata

\section{Discussion}

\section{Note on Asteraceae Species in Citalahab}

Several Asteraceae species at tea plantation, Citalahab village, are categorized well as introduce, weed, or even invasive alien species in Java (Kostermans, et al., 1987; Zachariades, et al., 2009; Sunaryo, et al. 2012; Yoshihumi, et al. 2014; Padmanaba, et al. 2017). Most of species originally come from South, Central, and North America long time ago, except $C$. crepidioides that native to tropical Africa. Only A. lavenia, E. sonchifolia, and $L$. indica that has wide distribution in Old World including Asia tropical to Pacific, make that likely native in Malesia (Backer \& Bakhuizen van den Brink 1965; Shi, et al., 2011; Monge, et al., 2016; Nisyawati \& Mustaqim, 2017).

Adenostemma lavenia has number varieties across region. Panigrahi (1975) studied that there are eight varieties within species in India region. Though this taxa has complex issues, but all the varieties has similar ecological condition to grow-well in shades and near water resource. Species A. lavenia already reported tend to grow under the shade and humid localities in Java (Backer \& Bakhuizen van den Brink, 1965). That report has same condition with the ecology of two A. lavenia varieties in Australia which were found on the edge of creeks and swamps (Orchard, 2011). Besides, A. lavenia that 
found at Leuser, Aceh, has similar location on high mountains (Tjitrosoedirdjo, 2002). That created a note that edge effect of the areas has potential concern to overpopulated this species.

Ayapana triplinervis, write as Eupatorium triplinerve in Flora of Java, comes from Brazil (Backer \& Bakhuizen van den Brink, 1965). This species spread to Java long time ago, but noted that rarely found in flowering phase. The expand and reproducing of the species often using rooting stem, wich seems not very effective for population growth. However, presence of $A$. triplinerve were not harmless. In Gunung Halimun-Salak National Park, the species already occur and become threat at three others southern areas (Uji, 2002).

Several ways to control the introduced species have been done by local people intentionally or not. Tea plantation has regular rejuvenation pruning. Weeds around the tea plant included in that field clearance, so that several Asteraceae species would lost periodically. That is more or less useful, though that still too hard to control the weeds to spread across large open areas around the national park. It must be consider that alien plant species are usually introduced and grew by several ways on purpose or not (Pons, et al. 1987; Westaway, et al. 2018).

The other way to control the population may comes from medicine, food, and livestock collecting. Generally, almost Asteraceae species in Indonesia, especially Halimun, are usable. Several sundanese ethnics often use $A$. conyzoides, C. odorata, E. valerianifolia, and A. inulaefolium with another species within the family for medicinal and food resource purposes (Sihotang, 2011; Putri, et al., 2016; Malini, et al., 2017). Most species even often used for livestock fodder and insects invitee, include for honey bee Apis cerana (Kostermans, et al., 1987; Jasmi, 2017). Therefore, local people has important role to control the population of introduced species.

\section{A New Record of Alien Plant Species}

Genera Elephantopus L., (Asteraceae, Vernonieae) are widely spread from old world to new world with about 28 species (Keeley \& Robinson, 2009). The genera apparently arose from New World Andean-based according to lineage (Keeley, et al. 2007). Within the Malesia subcontinental region of botany, genera Elephantopus are already recorded for Java (Backer \& Bakhuizen van den Brink, 1965), Sumatra (Tjitrosoedirdjo, 2002), Peninsular Malaysia (Hashim, etl al. 2010), Borneo (Indra, et al. 2014), Sulawesi (Syah, et al. 2014; Rugayah, et al. 2015), to Lesser Sunda Islands (Westaway, et al. 2018).

Elephantopus had been found in the field observation has no match from any record in Java. After following examination, the species identified match as E. Mollis. This species was already reported by Moody (1989) to occurs as a weed in South East Asia, but it was recorded from The Phillipines and without mentioning the Indonesia as the sources of the record. Later, record from several main islands are available, such as Sumatra (Tjitrosoedirdjo, 2002), Borneo (Indra, et al. 2014), Sulawesi (Syah, et al. 2014; Rugayah, et al. 2015), and Lesser Sunda Islands (Westaway, et al. 2018). Besides, E. Mollis has long distance dispersal in the tribal history to move across the ocean (Keeley, et al. 2007), so that E. mollis occurance in Java has strong reasons.

\section{Taxonomic treatments}

Elephantopus mollis Kunth in Humb., Bonpl. \& Kunth, Nov. Gen. Sp. 4(14): 26. 1820. - Type: Venezuela, Caracas, Humboldt \& Bonpland no. 627 (holotype: P!),

Description: Herbs, $1 \mathrm{~m}$ tall. Stems erect or procumbent, terete or inconspicuously angled, hair pilose, whitish colored. Leaves rosulate at lower part, alternate upper part; sometimes with up to 2 foliage stipules, ovate to elliptic; petiole up to $10 \mathrm{~mm}$ or almost absent; lamina elliptic, oblong, to oblong-sphatulate, $10-16 \mathrm{~cm}$ long, 2$5,5 \mathrm{~cm}$ wide, base attenuate, margin crenate, slightly undulate near the base, apex acute; slightly coriaceous; both surfaces pilose; cauline leaves oblong-elliptic, oblong, to oblonglanceolate, $2,5-8 \mathrm{~cm}, 0,5-3,5 \mathrm{~cm}$ wide. Heads terminal and axillary, branched; foliage bracts 3 , deltoid; capitula tubular, 7-8 $\mathrm{mm}$ long; receptacle flat, about $1 \mathrm{~mm}$ in diam., glabrous; involucres tubular, $6.5-8 \mathrm{~mm}$ long, 3-4 $\mathrm{mm}$ in diam. Phyllaries 8 , in 2 series, decussate, light green, margin entire, outer surface puberulous, without glands; the outer ovate, apex acute; the inner ones lanceolate, apex acuminate. Florets 4; corolla white, zygomorphic, glabrous; corolla tubes slender, 3-5 mm long, with 5 lobes, 1.5-2 $\mathrm{mm}$ long; anthers ca. $1 \mathrm{~mm}$ long, apical appendage acute, base rounded; styles white, 4$5 \mathrm{~mm}$ long, branches ca. $1 \mathrm{~mm}$ long. Cypsela clavate, $2.5-3 \mathrm{~mm}$ long, pubescent, densely covered with twin hairs but lacking glands, inconspicuously ribbed; pappus consist of 5 
bristles in one series, sigmoid at base, $3-5 \mathrm{~mm}$ long.

Distribution: Native to tropical America. Naturalized In Java at tea plantation HalimunSalak (1049-1149 m asl) down to sub-district Nanggung, Bogor, and seen also in Cikole, subdistrict Lembang, Bandung Regency, below the shade of Pinus trees.

Specimens examined: West Java, Citalahab, tea plantation, Dee Dee Al Farishy, DEE036A (Herbarium UI); West Java, Citalahab, tea plantation, Dee Dee Al Farishy, DEE036B (Herbarium UI); West Java, Citalahab, tea plantation, Dee Dee Al Farishy, DEE039 (Herbarium UI); West Java, Citalahab, tea plantation, Dee Dee Al Farishy, DEE050 (Herbarium UI ).

Ecology: from open areas such as tea plantation to shady condition below Pinus forest, up to 1100 $\mathrm{m}$ asl.

Phenology: The species has been seen flowering in July 2018 at Cikole, Bandung Regency, West Java, then found flowering again in January 2019 at Citalahab, West Java. This phenology is different than related taxa E. Scaber that flowering only during the peak of drought season, from July to Oktober.

Note: distinguished by having larger leaves on the erect stem (vs few and small E. scaber) and predominantly white colored on whole corolla part (vs purple or violet on limb E. scaber).

\section{Acknowledgment}

Thanks to Isnaenisa Rachma, Nur Avifah, and Zahrah Afifah for help collecting specimens on the field. Thanks to Wendy Achmmad Mustaqim for voluntary discuss and review the article. Thanks to Department biology, Faculty Mathematics and Natural Sciences to deposit the specimens.

\section{References}

Backer, C.A. \& Bakhuizen van den Brink Jr, R.C. (1965). Flora of Java, Volume II. N.V.P. Nordhoff, Groningen. ISBN:-, pp: (73) + 641.

Bunwong, S., Chantaranotai, P. \& Keeley, S.C. (2014). Revision and key to the
Vernonieae (Compositae) in Thailand. PhytoKeys 37: 25-101. DOI: https://doi.org/10.3897/phytokeys.37.649 $\underline{9}$

Christenhusz, M.J.M. \& Byng, J.W. (2016). The number of known plants species in the world and its annual increase. Phytotaxa 261(3): 201-217. DOI: http://dx.doi.org/10.11646/phytotaxa.261. 3.1

Cox, C. B., Moore, P.D. \& Ladle, R.. (2016). Biogeography: An Ecological and Evolutionary Approach, Ninth Edition. John Wiley \& Sons, Inc., New Jersey, USA. ISBN: 978-1-118-96857-4, pp: xiii $+500$

Funk, V.A., Anderberg, A.A., Baldwin, B.G., Bayer, R.J., Bonifacino, J.M., Breitwieser I., Brouillet, L., Carbajal, R., Chan, R., Coutinho, A.X.P., Crawford, D.J., Crisci, J.V., Dillon, M.O., Freire, S.E., GalbanyCasals, M., Garcia-Jacas, N., Gemeinholzer, B., Gruenstaeudl, M., Hansen, H.V., Himmelreichm S., Kadereit, J.W., Källersjö, M., KaramanCastro, V., Karis, P.O., Katinas, L., Keeley, S.C., Kilian, N., Kimball, R.T., Lowrey, T.K., Lundberg, J., McKenzie, R.J., Tadesse, M., Mort, M.E., Nordenstam, B., Oberprieler, C., Ortiz, S., Pelser, P.B., Randle, C.P., Robinson, H., Roque, N., Sancho, G., Semple, J.C., Serrano, M., Stuessy, T.F., Susanna, A., Unwin, M., Urbatsch, L., Urtubey, E., Vallès, J., Vogt, R., Wagstaff, S., Ward, J. \& Watson, L.E.. (2009). Compositae metatrees: the next generation. In: Systematics, Evolution, and Biogeography of Compositae. International Association for Plant Taxonomy, Vienna, Austria, pp: 747-777. ISBN: 978-3-9501754-3-1

Hashim, N.R., Hughes, F. \& Bayliss-Smith, T. (2010). Non-native Species in Floodplain Secondary Forests in Peninsular Malaysia. EnvironmentAsia 3: 43-49. DOI: 10.14456/ea.2010.38

Hartono, T., Kobayashi, H., Widjaya, H. \& Suparmo, M. (2007). Taman Nasional Gunung Halimun Salak "Menyingkap Kabut Gunung Halimun Salak" Edisi Revisi. JICA-BTNGHS-Puslit Biologi LIPI-PHKA, Bogor. ISBN: 979-579-017$\mathrm{X}, \mathrm{pp} . \mathrm{vi}+48$.

Indra, Husni, H. \& Sisilia, L. (2014). Kajian etnobotani tumbuhan obat etnis Melayu di 
Desa Sempadian Kabupaten Sambas. Jurnal Hutan Lestari 2(2): 181-188. DOI: http://dx.doi.org/10.26418/jhl.v2i2.5839

Irsyam, A.S.D. \& Hariri, M.R.. (2016). Eupatorium capillifolium (Lam.) Small ex Porter \& Britton (Asteraceae: Eupatorieae), new record for Flora of Java. Journal of Biology 9(2): 80-86. DOI: https://doi.org/10.15408/kauniyah.v9i2.33 35

Jasmi. (2017). Diversity and blooming season of food sources plant of Apis cerana (Hymenoptera: Apidae) in polyculture plantation in West Sumatra, Indonesia. Biodiversitas 18(1): 34-40. DOI: https://doi.org/10.13057/biodiv/d180106

Jeffrey, C. (2009). Evolution of Compositae Flowers. In: Systematics, Evolution, and Biogeography of Compositae. International Association for Plant Taxonomy, Vienna, Austria, pp: 131-138. ISBN: 978-3-9501754-3-1

Keeley, S.C., Z.H. Forsman \& R. Chan. (2007). A phylogeny of the "evil tribe" (Vernonieae: Compositae) reveals Old/New World long distance dispersal: Support from separate and combined congruent datasets (trnL-F, $n d h \mathrm{~F}$, ITS). Molecular Phylogenetics and Evolution: 44: 89-103. DOI: https://doi.org/10.1016/j.ympev.2006.12.0 $\underline{24}$

Keeley, S.C. \& Robinson, H. (2009). Vernonieae. In: Systematics, Evolution, and Biogeography of Compositae. International Association for Plant Taxonomy, Vienna, Austria, pp: 439-469. ISBN: 978-3-9501754-3-1.

Kostermans, A.J.G.H., S. Wirjahardja \& R.J. Dekker. (1987). The Weeds: Description, Ecology and Control. In: Weeds of Rice in Indonesia. Balai Pustaka, Jakarta. ISBN: 979-407-004-1, pp: 24-565.

Malini, D.M., Madihah, Kusmoro, J., Kamilawati, F. \& Iskandar, J. (2017). Ethnobotanical Study of Medicinal Plants in Karangwangi, District of Cianjur, West Java. Biosaintifika 9(2): 345-356. DOI: 10.15294/biosaintifika.v9i2.5756

Moody, K. (1989). Weeds Reported in Rice in South and Southeast Asia. International Rice Research Institute, Los Baños, Laguna, Philippines. ISBN: 971-104-2061, pp: viii +442 .
Monge, M., Kilian, N., Anderberg, A.A. \& Semir, J. (2016). Two new records of Lactuca L. (Cichorieae, Asteraceae) in South America. Brazilian Journal of Biosciences 14(2): 117-123.

Nisyawati \& Mustaqim, W.A. (2017). A Guide to the Urban Plants of Universitas Indonesia: Spermatophytes. UI Press, Jakarta. ISBN: 978-979-456-705-0, pp: vi $+863$

Padmanaba, M. Tomlinson, K.W., Hughes, A.C. \& Corlett, R.T. (2017). Alien plant invasions of protected forest areas in Java, Indonesia. Scientific Reports 7(9334): 111. DOI: https://doi.org/10.1038/s41598017-09768-Z

Panigrahi, G. (1975). The Genus Adenostemma (Compositae) in the Indian Region. Kew Bulletin 30(4): 647-655. DOI: https://doi.org/10.2307/4102906

Pons, T.L., Eussen, J.H.H. \& Utomo, I.H. 1987. Ecology of Weeds of Rice. In: Weeds of Rice in Indonesia. Balai Pustaka, Jakarta. ISBN: 979-407-004-1, pp: 15-23.

Priyadi, H., G. Takao, I. Rahmawati, B. Supriyanto, W.I. Nursal \& I. Rahman. 2010. Five Hundred Plants Species in Gunung Halimun-Salak National Park, West Java; a checklist including Sundanese names, distribution, and use. CIFOR, Bogor, Indonesia. ISBN: 978602-8693-22-6, pp: vii + 181 .

Putri, L.S.E., Dasumiati, Kristiyanto, Mardiansyah, C. Malik, L.P. Leuvinadrie \& E.A. Mulyono. 2016. Ethnobotanical study of herbal medicine in Ranggawulung Urban Forest, Subang District, West Java, Indonesia. Biodiversitas 17(1): 172-176. DOI:

https://doi.org/10.13057/biodiv/d170125

Rugayah, S. Sunarti, D. Sulistiarini, A. Hidayat \& M. Rahayu. 2015. Daftar Jenis Tumbuhan di Pulau Wawonii, Sulawesi Tenggara. LIPI Press, Bogor. ISBN: 978979-799-845-5, pp: xvii + 363.

Shi, Z., Chen, Y., Chen ,Y., Lin, Y., Liu, S., Ge, X., Gao, T., Zhu, S., Liu, Y., Yang, Q., Humpries, C.J., von Rabb-Straube, E. Gilbert, M.G., Nordenstam, B., Killian, N., Brouillet, L., . Illarionova, I.D., Hind, D.J.N., Jeffrey, C., Bayer, R.J., Kirschner, J., Greuter, W., Anderberg, A.A., Semple, J.C., Štěphánek, J., Freire, S.E., Martins, L., Koyama, H., Kawahara, T., Vincent, L., Sukhorukov, A.P., Maurodiev, E.V. \& 
Gottschlich, G. (2011). Flora of China volume 20-21 (Asteraceae). Science press, Beijing. ISBN: 978-1935641070, pp. 993.

Sihotang, V.B.L. 2011. Ethnomedicinal study of the Sundanese people at the Bodogol area, Gede Pangrango Mountain National Park, West Java. Gardens' Bulletin Singapore 63(1 \& 2): 519-526.

Sunaryo, Uji, T. \& Tihurua, E.F. (2012). Species composition and threat potential of invasive plants species in Gunung Halimun-Salak National Park, West java. Berita Biologi 11(2): 231-239. DOI: https://doi.org/10.14203/beritabiologi.v11 $\underline{\mathrm{i} 2.493}$

Syah, A.S., Sulaiman, S.M. \& Pitopang, R. (2014). Jenis-jenis tumbuhan suku Asteraceae di Desa Mataue, kawasan Taman Nasional Lore Lindu. Online Jurnal of Natural Science 3(3): 297-312. DOI:

https://doi.org/10.22487/25411969.2014.v 3.i3.3340

Tjitrosoedirdjo, S.S. (2002). Notes on the Asteraceae of Sumatra. Biotropia 19: 6584.

DOI: https://doi.org/10.11598/btb.2002.0.19.23 $\underline{0}$

Uji, T. (2002). Plant Diversity and Their Potential in Mount Halimun and Surrounding Areas in Gunung Halimun National Park. Berita Biologi 6(1): 1-12.

Westaway, J., Quintao, V. \& de Jesus Marcal, S. (2018). Preliminary checklist of the naturalised and pest plants of Timor-Leste. Blumea 63: 157-166. DOI; https://doi.org/10.3767/blumea.2018.63.0 $\underline{2.13}$

Wisnubudi, G. (2009). Penggunaan strata vegetasi oleh burung di kawasan wisata Taman Nasional Gunung Halimun-Salak. Vis Vitalis 2(2): 41-49.

Yoshihumi, K., Mutaqien, Z., Simbolon, H. \& Suzuki E. (2014). Spread of invasive plants along trails in two national park in West Java, Indonesia. Tropics 23(3): 99110.

DOI: https://doi.org/10.3759/tropics.23.99

Zachariades, C., Day, M., Muniappan, R. \& Reddy, G. V. P. (2009). Chromolaena odorata (L.) King and Robinson (Asteraceae). In: Biological Control of Tropical Weeds Using Arthropod. Cambridge University Press, Cambridge. ISBN: 9781107411265, pp: 130-162. 
Table 1. Checklist of Asteraceae on tea plantation, Citalahab village, Gunung Halimun-Salak National Park

\begin{tabular}{|c|c|c|c|c|c|c|c|c|}
\hline No. & Tribe & Species & $\mathrm{RF}$ & VI & TP1 & TP2 & TP3 & $\mathrm{CM}$ \\
\hline 1 & Astereae & Erigeron sumatrensis Retz. & $\checkmark$ & $\checkmark$ & $\checkmark$ & $\checkmark$ & $\checkmark$ & - \\
\hline 2 & Cichorieae & Lactuca indica $\mathrm{L}$. & - & $\checkmark$ & - & - & - & - \\
\hline 3 & Eupatorieae & Adenostemma lavenia (L.) Kuntze & - & - & - & - & - & $\checkmark$ \\
\hline 4 & Eupatorieae & Ageratum conyzoides (L.) L. & $\checkmark$ & $\checkmark$ & $\checkmark$ & $\checkmark$ & $\checkmark$ & - \\
\hline 5 & Eupatorieae & Austrouepatorium inulaefolium (Kunth) R.M.King \& H.Rob. & $\checkmark$ & $\checkmark$ & $\checkmark$ & $\checkmark$ & $\checkmark$ & - \\
\hline 6 & Eupatorieae & Ayapana triplinervis (Vahl) R.M.King \& H.Rob. & $\checkmark$ & - & - & - & - & - \\
\hline 7 & Eupatorieae & Chromolaena odorata (L.) R.M.King \& H.Rob. & $\checkmark$ & $\checkmark$ & $\checkmark$ & - & $\checkmark$ & - \\
\hline 8 & Eupatorieae & Mikania micrantha Kunth & $\checkmark$ & $\checkmark$ & $\checkmark$ & - & $\checkmark$ & - \\
\hline 9 & Heliantheae & Acmella paniculata (Wall. ex DC.) R.K.Jansen & $\checkmark$ & $\checkmark$ & $\checkmark$ & $\checkmark$ & $\checkmark$ & - \\
\hline 10 & Heliantheae & Bidens pilosa $\mathrm{L}$. & $\checkmark$ & $\checkmark$ & $\checkmark$ & $\checkmark$ & $\checkmark$ & - \\
\hline 11 & Heliantheae & Calyptocarpus vialis Less. & $\checkmark$ & $\checkmark$ & $\checkmark$ & $\checkmark$ & $\checkmark$ & - \\
\hline 12 & Heliantheae & Clibadium surinamense $\mathrm{L}$ & $\checkmark$ & $\checkmark$ & $\checkmark$ & - & $\checkmark$ & - \\
\hline 13 & Heliantheae & Eclipta prostrata (L.) L. & $\checkmark$ & $\checkmark$ & $\checkmark$ & $\checkmark$ & $\checkmark$ & - \\
\hline 14 & Heliantheae & Galinsoga parviflora $\mathrm{Cav}$. & $\checkmark$ & $\checkmark$ & $\checkmark$ & $\checkmark$ & $\checkmark$ & - \\
\hline 15 & Heliantheae & Sphagneticola trilobata (L.) Pruski & $\checkmark$ & $\checkmark$ & $\checkmark$ & $\checkmark$ & $\checkmark$ & - \\
\hline 16 & Heliantheae & Synedrella nodiflora (L.) Gaertn. & $\checkmark$ & $\checkmark$ & $\checkmark$ & $\checkmark$ & $\checkmark$ & - \\
\hline 17 & Senecionae & Crassocephalum crepidioides (Benth.) S.Moore & $\checkmark$ & $\checkmark$ & $\checkmark$ & $\checkmark$ & $\checkmark$ & - \\
\hline 18 & Senecionae & Emilia sonchifolia (L.) DC. ex DC. & $\checkmark$ & $\checkmark$ & $\checkmark$ & $\checkmark$ & $\checkmark$ & - \\
\hline 19 & Senecionae & Erechtites valerianifolia (Link ex Wolf) Less. ex DC. & $\checkmark$ & $\checkmark$ & $\checkmark$ & - & $\checkmark$ & - \\
\hline 20 & Vernonieae & Elephantopus mollis Kunth & $\checkmark$ & $\checkmark$ & $\checkmark$ & $\checkmark$ & $\checkmark$ & - \\
\hline
\end{tabular}




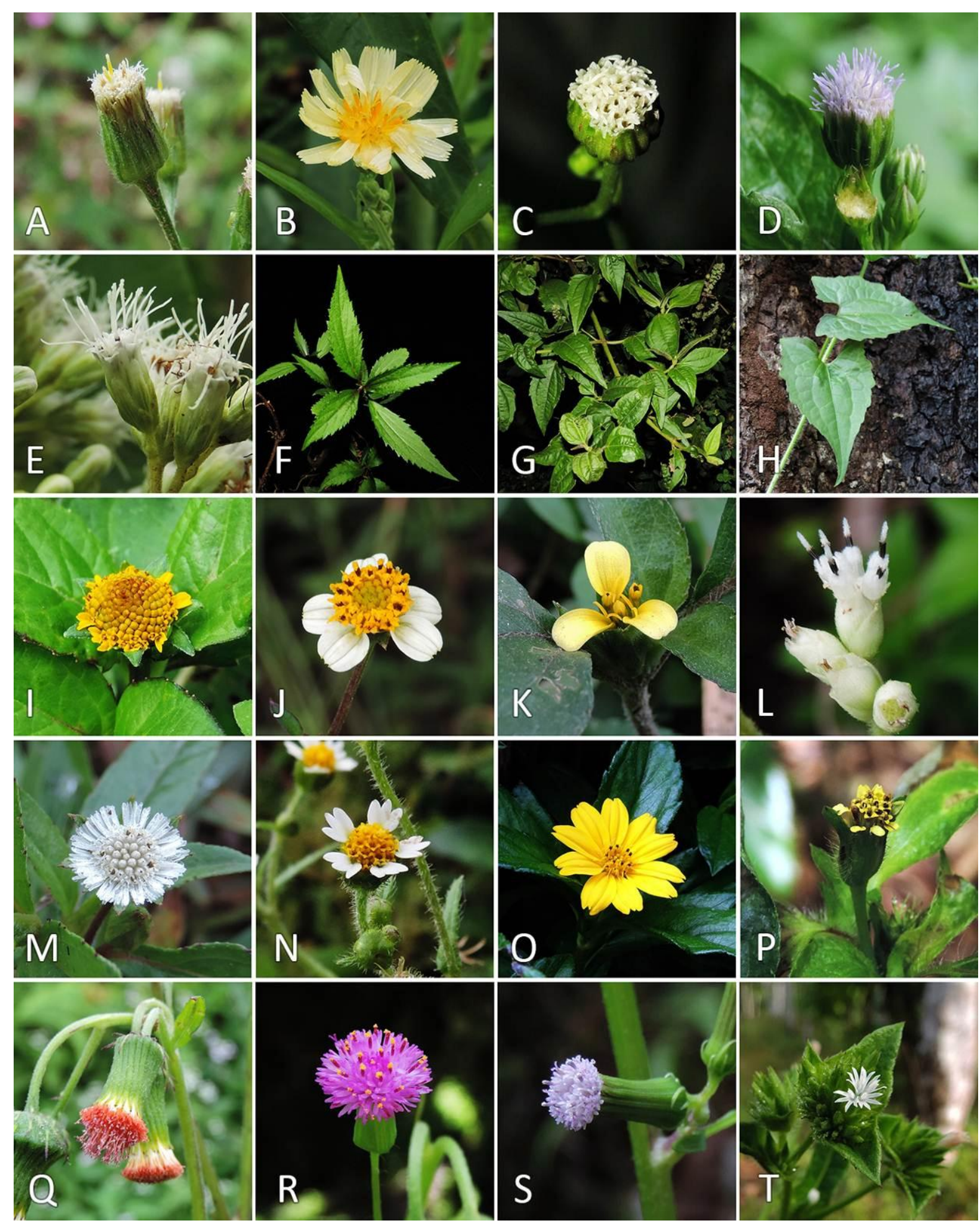

Figure 1. Asteraceae at Citalahab A. Astereae: Erigeron sumatrensis. B. Cichorieae: Lactuca indica. C-H.

Eupatorieae: Adenostemma lavenia; Ageratum conyzoides; Austroeupatorium inulaefolium; Ayapana triplinervis; Chromolaena odorata; Mikania micrantha. I-P. Heliantheae: Acmella paniculata; Bidens pilosa; Calyptocarpus vialis; Clibadium surinamense; Eclipta protrata; Galinsoga parviflora; Sphagneticola trilobata; Synedrella nodiflora. Q-S. Senecioneae: Crassocephalum crepidioides; Emilia sonchifolia; Erechtites valerianifolia. T. Vernonieae: Elephantopus mollis 


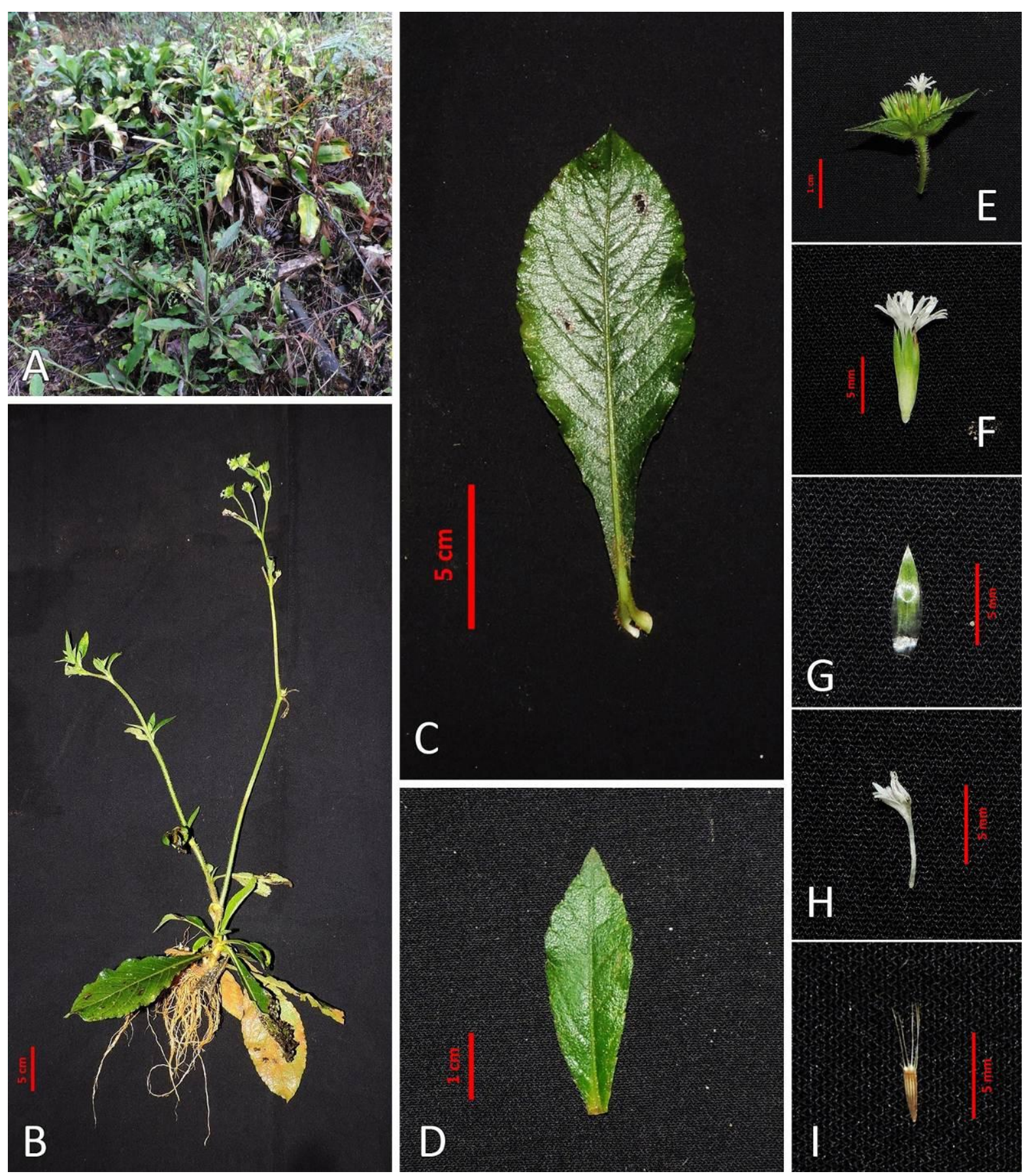

Figure 2. Elephantopus mollis A-B. Habitus. C. Rossete leaf. D. Cauline leaf. E. Head. F. Florets. G. Involucre. H. Flower. I. Cypsela. 